られる。

これについては伊藤 ${ }^{18)}$ の実験によれば $\mathrm{NaOH} 145 \mathrm{~g} / l$, モル比 $0.49,40^{\circ} \mathrm{C}$ の析出条件に打いて, $\mathrm{Na}_{2} \mathrm{CO}_{3} 20 \sim 30 \mathrm{~g} / \mathrm{l}$ まで添加す ると析出速度の増加が認められて扣り，その原因としては $\mathrm{Na}_{2} \mathrm{O}$. $\mathrm{Al}_{2} \mathrm{O}_{3} \cdot 4 \mathrm{CO}_{2} \cdot x \mathrm{H}_{2} \mathrm{O}$ なる複塩の生成のためか, 水酸化アルミニウ 么粒子の凝集を起すためのいずれかであるとしている。

更に木村 ${ }^{19)}$ によれば $\mathrm{NaOH}$ の中の $0 \sim 20 \mathrm{~g} / l$ 程度を $\mathrm{Na}_{2} \mathrm{CO}_{3}$ に置換せしめると置換量が多いほど析出量が増すといっている。 かかる実験的事実から推論すれば，工業液に拈ける析出速度の增 加の原因は炭酸ナトリウムに起因するものと考えられる。更に後 述すると括り，液中に炭酸ガスを多くもたらす空気かきまぜに おいては析出物中に含有するナトリウム分を多くするという事夷 は，析出の促進が伊藤のいうような複塩の生成に起因するものと 思われる。

他の塩, すなわち塩化ナトリウム, 硫酸ナトリウムについては 塩田 ${ }^{20)}$ ，木村の実験があり，いずれも悪い影響があるといってい る。Pearson ${ }^{21)}$ は通常の純アルミン酸ナトリウム溶液において法 析出速度は次式に従うとしている。

$$
-\frac{\mathrm{d} C_{\mathrm{a}}}{\mathrm{d} \theta}=K A_{\mathrm{t}}\left(\frac{C_{\mathrm{a}}-C_{\mathrm{as}}}{C_{\mathrm{n}}}\right)
$$

18）伊藤，フルミニウム 3 ，A 192 (1943).

19）木村，フルミニウム 4, A 132 (1944).

20) 塩田，アルミニウム 3，49 (1943).

21) T. G. Pearson, "The Chemical Background of Aluminium Industry" p. 30 (1955), W. Heffer \& Sons Ltd, Cambridge.

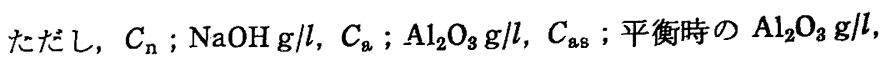
$A_{\mathrm{t}}$; 種子表面積, $K$; 反応速度定数とする。工業用溶液を使用し た場合には $C_{\mathrm{ass}}$ が $C^{\prime}{ }_{\mathrm{as}}\left(C_{\mathrm{as}}<C^{\prime}{ }_{\mathrm{as}}\right)$ に変化するので析出速度は

$$
-\frac{\mathrm{d} C_{\mathrm{a}}}{\mathrm{d} \theta}=K A_{\mathrm{t}}\left(\frac{C_{\mathrm{a}}-C_{\mathrm{aB}}^{\prime}}{C_{\mathrm{n}}}\right)^{2}
$$

となり，毒作用係数として

$$
k=\frac{C_{\mathrm{as}}^{\prime}-C_{\mathrm{as}}}{C_{\mathrm{as}}} \text {. }
$$

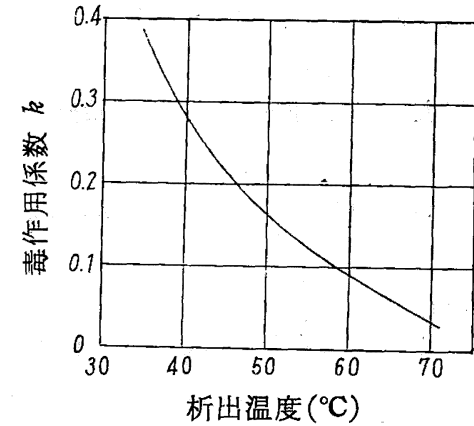

図 20 毒作用係数 (Pearson Kよる)
を定義すれば, $k$ は濃度が 一定ならば, 高温程減少し 毒作用の低下することを示 している（四 20)。この結 果はいずれの場合でも純液 より析出速度が小さくなる ことを意味し，先に示した 実験的事実と食違ってい る。おそらく使用した工業 用アルミン酸ナトリウム溶 液中の不純物成分のちがい

から来るものであろう。

一般に有機物が析出を阻害することは Pearson，木村の実験で も述べられている。たた，デンプンだけは佐藤 ${ }^{22)}$ の実験によると 析出速度を促進する。

本報告の終に当り，発表の機会を与えていただき，かつ種々の 御指導, 御援助を賜わった昭和電工一方井卓雄重役, 松原一郎工 場長を始め, 諸先䨿の方々に深く感謝の意を表わす。

\title{
アルミン酸ナトリウム溶液からの水酸化アルミニウムの 析出物粒度に対する溶液の温度および組成の影響†
}

(昭 和 37 年 3 月 20 日受 理)

\author{
下里純一郎**古川晶 久 $^{* *} \cdot$ 高 橋一太
}

\begin{abstract}
バイヤー法によるアルミナ製造工程に扣いてアルミン酸ナトリウム溶液から析出する水酸化アルミニゥムの性状は, 析 出工程以後の工程すなわち結晶の溶液からの分離, 脱水, 並びに焼成してアルミナを生成する諸工程の能率を支配する上 で重要である。本報に拈いては析出物の粘度に影響を及ぼす反応諸条件の中から，溶液の温度並びに組成を選び，これら の要因による変動を調べた実験を行ない，更に従来の文献上の実験例をも加えてその影響を論じた。この結果，次のよう な傾向が指摘された。（1）析出初温並びに析出過程の温度経過はともに高温の方が析出物の粒度は大になる。ただし析 出過程の温度よりも析出初温の方が影響は大きい。（2）アルカリ濃度の影響は高温に括けるょりも低温の方が著しい。 高温ではフルカリ濃度の濃い方が若干細かい析出物を生成するが，低温では粒度が最も細かくなるアルカリ濃度が存在 し，かつ低温になるに従い，その最小点はアルカリ濃度の薄い方に移る。
\end{abstract}

\section{1 緒言}

アルミン酸ナトリウム溶液から析出する際の水酸化アルミニウ ムの純度は反応条件によって，多種多様の変化を受ける。析出反 応の条件を核が発生し易く，過飽和度の高い条件汉って，しか

$\dagger$ 本報を「アルミナ製造工程より見たアルミン酸ナトリウム 溶液からの水酸化アルミニウムの析出反応（第 5 報）」と する。

* 昭和ネオプレン株式会社技術部：東京都港区芝宮本町

** 昭和電工株式会社横浜工場：横浜市神奈川区恵比須町
も活性ある種子を使えば，細粒が発生するし，その逆の条件で反 応を行なわせれば粗粒を製造することができる。アルミナの製造 工程においては，一般に反忘速度を促進せしめるように析出条件 を維持することも必要であるが，生成した析出物の処理を考慮す れば、析出物があまりに微細な結晶であっては思わしくない。し たがって析出条件を選ぶこは，主として両者が適当に満足し合う ような条件を見出だすことが必要である。反応条件を决定する要 因として，本報に颃いては温度，液組成を取り上げ，析出物粓度 に対する影響を調べる。 


\section{2 温度}

溶液から生成する結晶は，一般的には温度の高い条件から粗粒 の得られるのが常識で, 水酸化アルミニウムの析出結晶に执いて も例外ではない。これは高温に扣いて結晶の成長速度が大になる ためと析出物の結晶の形状が安定化して来るためと考光られる。

\section{$2 \cdot 1$ 温度の影響に対する析出実験}

析出物の性状を調べるために前報1)に述べた析出実験に拈いて 析出物の粓度を測定した。測定法はアンドレアゼンピペットによ る沈降分析で行なった。実験条件並びに結果は表 1 のと括りであ る。ただし種子の粒度は $55 \mu$ 以上 $69 \% ， 40 〜 55 \mu$ 16\%，30〜 $40 \mu 7 \%, 20 \sim 30 \mu 4 \%, 5 \sim 20 \mu 3 \%, 5 \mu$ 以下 1\%であって, 種子量は液中のアルミナ濃度に対して No. 7 が 41 当量 $\%$, No. 8 が 66 当量 \%, 他は 50 当量\%であった。析出時間は No. 5 , 6 が 120 時間で他は 88〜99 時間である。

温度の影響を示すために $40 \mu$ 以上㧊よび $20 \mu$ 以下の各条件 における析出物成分を各アルカリ濃度の水準で温度との関係を画 くと図 1 および 2 のうになる。溶液中の濃度の薄い範囲では温

表 1 析出物粒度分布

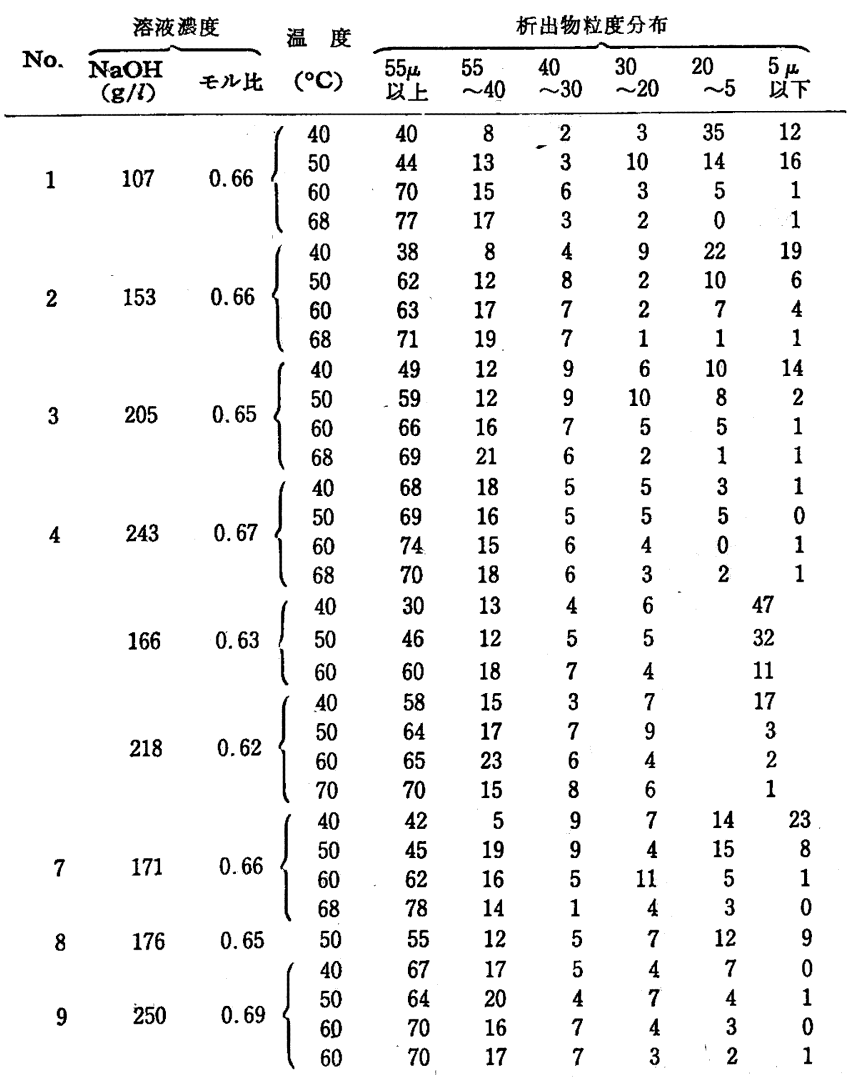

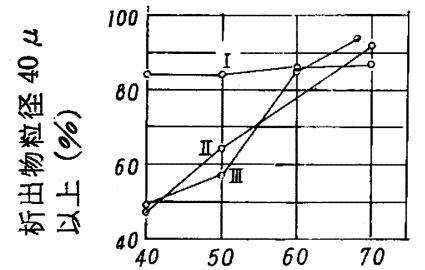

析出温度 $\left({ }^{\circ} \mathrm{C}\right)$

目 1 析出物粒度一温度の影響 $\mathrm{NaOH}(\mathbf{g} \mid l)$

I : 250 II $: 171 \quad$ III $: 107$

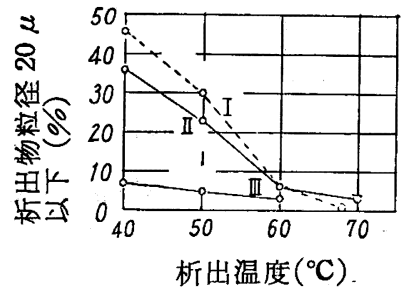

图 2 析出物粒度-温度の影響 $\mathrm{NaOH}(\mathrm{g} / \mathrm{l})$ I : $107 \quad$ II $: 171 \quad$ III $: 250$
1) 下里, 古川, 高橋, 工华 65, 1787 (1962).

表 2 析出物の粒度\%（伊藤に上る）

温度 $\left({ }^{\circ} \mathrm{C}\right)$

60

$\begin{array}{rr}110 & 187 \\ 0.9 & 7.6 \\ 2.1 & 6.3 \\ 46.2 & 31.6 \\ 43.0 & 44.0 \\ 7.8 & 10.5\end{array}$

度の影響が著しく大きく高温になるに従い粗粒部分が增加し，送 に細粒部分が減少する。しかしカセイソーダ濃度が濃くなると必 ずしも温度の影響は著しくない。

伊藤2)によれば炭酸ガス吹込によって析出させた活性種子を用 い, 種子量をアルミナ換算で $5 \mathrm{~g} / \mathrm{l}$ 用いた析出実験つ結果, 表 2 のような粒度の析出物を生じた。ただし溶液のモル比は 0.54 で ある。 $66^{\circ} \mathrm{C}$ で析出を行なったものの方が概して細粒の少ないる のを得ている。

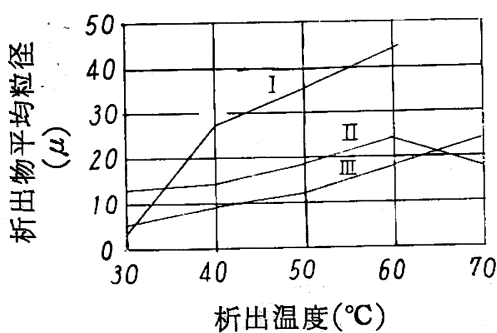

図 3 析出物粒度-温度の影響 （佐藤炕よる） $\mathrm{NaOH}(\mathrm{g} / l)$ I $: 80 \quad$ II $: 240 \quad$ III $: 140$

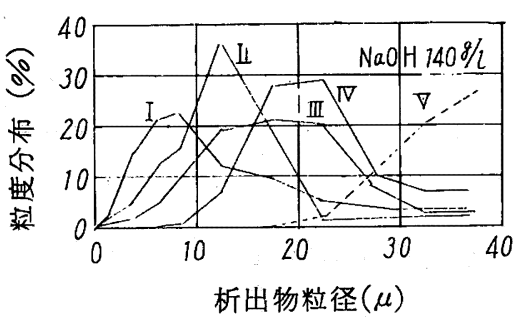

図 4 析出物粒度-温度の影響 (佐藤火よる) 析出温度 $\left({ }^{\circ} \mathrm{C}\right)$

I. 30 II $: 40$ III $: 50$ N $: 60 \mathrm{~V}: 70$

\section{$2 \cdot 2$ 中間実験}

工業的な析出反応においては定温析出ではないから, 初期温度 と温度過程とが粒度に影響を及 ぼす。中間実験において $\mathrm{NaOH}$ $157 \mathrm{~g} / l$, モル比 0.54 , 種子粒 度 $40 \mu$ 以上 $65 \%$, 種子量 60 $\mathrm{g} / l$, 析出時間 96 時間, 温度傾 斜 $\alpha=0.0043 \% 1$ 亿析出条件を 取った多くの実験から，初温と 析出物中の $40 \mu$ 以上の粗粒部 分との関係を求めると因 5 のよ うになる。また，種子粒度 20

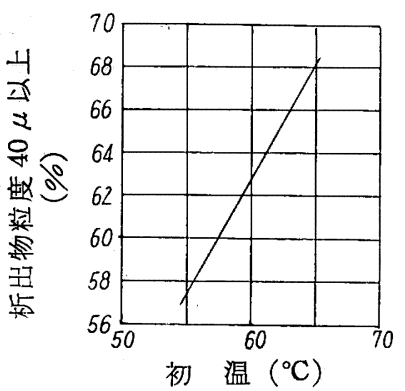

図 5 析出物粒度-初温の影響

2) 伊藤，フルミニゥム 3，A 120 (1943).

3）佐藤, 工化 57, 805 (1954).

※1 第 3 報に述べたと和りで, 初温 $t^{\circ} \mathrm{C}, \theta$ 時間後の温度 $t^{\circ} \mathrm{C}$ とする時, 析出液の温度過程は $t=t_{0} \exp (-\alpha \theta)$ なる式で 近似的に表現できた（ただし非連続式析出に拈いて）。 


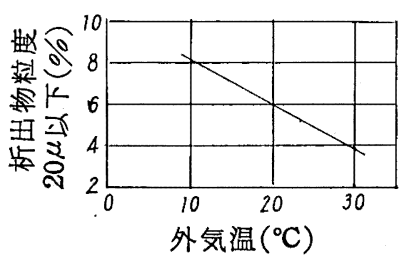

四 6 析出物粒度一外気温の影䇾

$\mu$ 以下 $8 \%$, 析出時間 105 時 間, 初温 $59^{\circ} \mathrm{C}$ として液組成, 種子量を図 5 の条件と同じに保 った場合の外気温※2すなわち 温度過程と析出物中の細粒部分 との関係を求めると図 6 のよ5 な傾向となる。析出時間 105 時 間目に扣けるこの条件の終温は外気温 $10^{\circ} \mathrm{C}$ の時に $42.5^{\circ} \mathrm{C}$, 外気 温 $30^{\circ} \mathrm{C}$ の時に $51.5^{\circ} \mathrm{C}$ であるから, 外気温の低下に伴なって低 温析出になり細粒部分が多くなって来る。したがって析出工程に おいては初温も析出途中の温度過程も高温な条件ほど, ”粗粒を析 出する。しかし四 5, 図6 を比較すれば, 初温の影響の方が外気 温すなわち温度傾斜の影響よりも大きい。これは析出反応の大部 分が析出初期に行なわれるために析出物粒度が析出初期 $20 \sim 30$ 時間内の条件で大体の傾向を決定付けられてしまうからである。

\section{3 液 組 成}

アルミン酸ナトリウム溶液はその濃度によって, 溶解度が著し く変って来るために析出物の粒度が核の発生数と結晶の成長速度

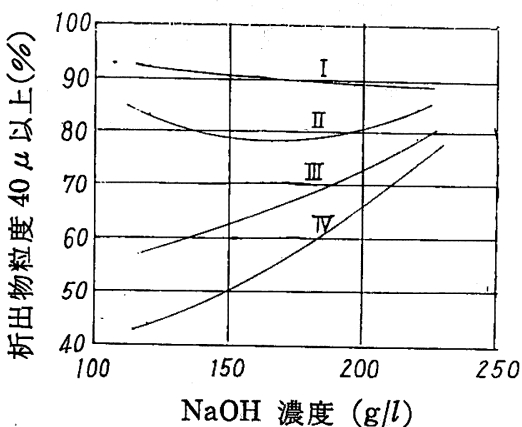

図 7 析出物粒度ーアルカリ濃度の影響 I $: 70^{\circ} \mathrm{C} \quad$ II $: 60^{\circ} \mathrm{C}$ III $: 50^{\circ} \mathrm{C} \quad$ IF $: 40^{\circ} \mathrm{C}$

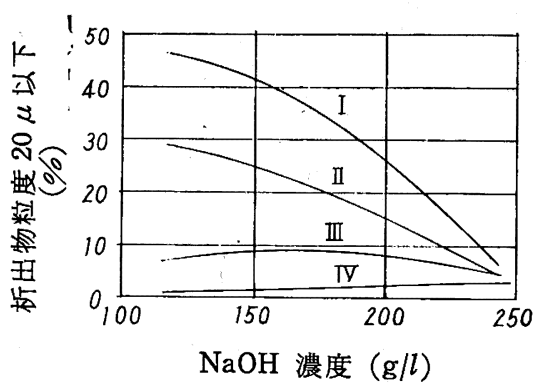

図 8 析出物粒度-アルカリ濃度の影響 I $: 40^{\circ} \mathrm{C} \quad$ II $: 50^{\circ} \mathrm{C} \quad$ III $: 60^{\circ} \mathrm{C} \quad$ IN $: 70^{\circ} \mathrm{C}$

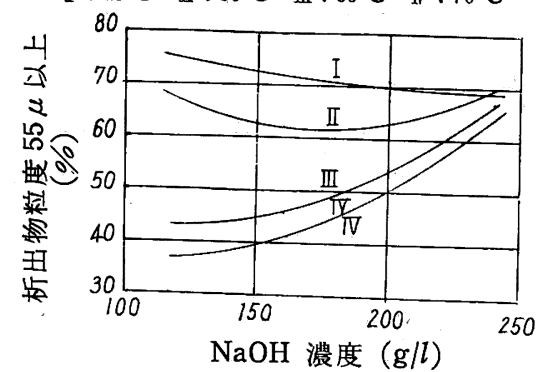

図 9 析出物粒度一アルカリ濃度の影響 I : $70^{\circ} \mathrm{C}$ II $: 60^{\circ} \mathrm{C}$ III : $50^{\circ} \mathrm{C} \quad$ II $: 40^{\circ} \mathrm{C}$

$※ 2$ 外気温と析出液の温度過程との関係は第 3 報参照（連続式 析出に和いて)，外気温が高いほど，その下降速度は緩かに なる。
カリ濃度の高い方では過飽和度の減少に伴ない核の発生速度が小 になる傾向があるが，アルカリ濃度の低い方では結晶が安定で機 械的強度が比較的強いものが析出する一方，核の発生速度す大に なる傾向が存在しているためと考えられる。そして，温度が低い 範囲に打いて低濃度の方が粒度の細かい傾向を有するのは結晶の 安定性に対するアルカリ濃度の影響が低温では少ないためと見る べきであり，温度の高い範囲においては核の発生速度と結晶の安 定性に対するアルカリ濃度の影響がほぼ釣合っているために析出 粒度がアルカリ濃度の影響によって変動しないるのと判断すべき であろう。アルカリ濃度の高、溶液から析出したものの方が種子 として使用した時に活性に富んでいることは前報）に述べたとお りであるが，このことはアルカリ濃度の高い方から析出した結晶 の方が不安定で機械的強度も弱いことを示している。析出に際し ては，必ず固体分を均一に浮遊させるだけのかきませ伴ならか ら, 析出反応中に打ける結晶の樹枝状部分等の分解現象が起って いる筈である。また，図8のように析出物中の細料部分とアルカ リ濃度の関係を示寸曲線では全く傾向が逆になっている。すなわ ち， $70^{\circ} \mathrm{C}$ ではアルカリ濃度の高い方が細粒部分多く，60

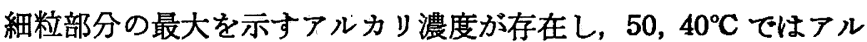
カリ濃度の低い方が細粒部分の多い水酸化物を析出する。

佐藤 ${ }^{5}$ によれば, 種子として $30^{\circ} \mathrm{C}$ で析出を行わせた活性種子 （粒度 $10 \mu$ 以下 $61 \% ， 35 \mu$ 以上 $2.4 \%$ ) を用い温度 $30^{\circ} \mathrm{C}$, 種 子量 $10 \%$, 析出時間 120 時間の析出条件でアルカリ濃度, モル 比を種々に変えて析出物の平均粒径を測定した結果，眓 10,11 のような傾向を示している。この条件では液温も低く，粒度の細

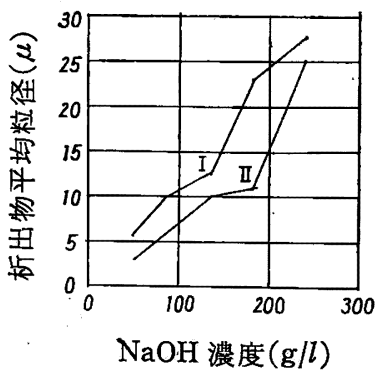

図 10 析出物粒度一アルカリ濃 度の影䭙（佐藤による）

$$
\text { I }: R=0.59
$$$$
\text { II }: R=0.43
$$

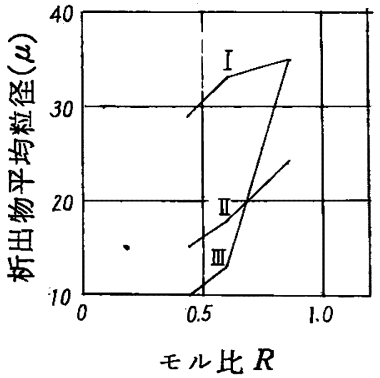

図 11 析出物粒度一モル比の影

響 (佐藤による) I : $\mathrm{NaOH} 240 \mathrm{~g} / l$
II $: \mathrm{NaOH} 140 \mathrm{~g} / l$
III $: \mathrm{NaOH} 80 \mathrm{~g} / l$
かい活性種子を用いている関係から，アルカリ濃度の高い方にお ける核発生の減少傾向のみが強調されたるのと解される。したが ってこの条件では, アルカリ濃度の低い範囲でも活性種子と低温 度の影響を受けて不安定な結晶を生じ, 結果としてアルカリ濃度 が高いほど粒度が粗くなっている。これは四 7，8，9 における低 温度の傾向とも一致する。また，モル比大なるほど粒度が粗くな るのは析出量の増大に伴なら結晶成長量の増加によるすのであろ ら。しかし，極度にモル比が大になれば，急激な析出に伴なって 不安定な結晶を生成するから，かえって細粒を発生するすのと考 えられる。

\section{$3 \cdot 2$ 中間実験}

中間実験において低アルカリ濃度で行なった析出実験の結果を 表 3 に示す。粒度分布の測定は析出物を乾燥し、フルイ分けによ

4) 下里, 工化 65,1792 (1962).

5）佐藤, 工化 57, 541 (1954). 
表 3 低フルカリ濃度に括ける析出物粒度
析出条件

No. $\mathrm{NaOH}$ モル 温度程子量析出㭙間 $100 \times 100 \quad 170 \quad 200325 \times$ $(\mathrm{g} / \mathrm{l})$ 比 $\left.{ }^{\circ} \mathrm{C}\right){ }_{(\%)}^{(\%)}(\mathrm{hr}){ }^{\circ}$ 以上 $170 \quad 200 \quad 325$ 以下

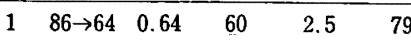
$\begin{array}{lllll}81 & 0.64 & 60 & 2.5 & 55\end{array}$ $\begin{array}{lllll}106 & 0.59 & 60 & 2.6 & 57\end{array}$ $\begin{array}{lllll}130 & 0.56 & 60 & 7.5 & 72\end{array}$ $\begin{array}{lllll}123 & 0.56 & 60 \rightarrow 44 & 3.5 & 64\end{array}$ $\begin{array}{llll}1.1 & 65.3 & 21.6 & 12.0\end{array}$ $\begin{array}{rrrr} & 29.2 & 69.7 & 1.1 \\ 0.7 & 31.8 & 12.5 & 55.0\end{array}$ $\begin{array}{lll}5.0 & 70.2 & 24.8\end{array}$ $51.0 \quad 41.0 \quad 8.0$ $\begin{array}{lllll}113 & 0.59 & 60 \rightarrow 44 & 3.8 & 71\end{array}$

った。実験 No. 1 は蒸気加熱によって温度を一定に維持したため に析出時間の経過に伴なって、アルカリ濃度は薄くなっている。 種子量は析出開始時におけるアルミナ濃度に対する当量 \%で表 現してある。この結果を見ればアルカリ濃度の薄い方が, 粒度の 粗いものを得られることが判明する。これは前記の実験結果にお いてアルカリ濃度が $100 \mathrm{~g} / l$ より薄い範囲では $60^{\circ} \mathrm{C}$ の温度にお いて，粒度の粗くなることを示唆しているのと一致する。前節に 述べたよらな中間実験で得られた結果から析出物中の細粒部分と アルカリ濃度の関係を示すと図 12,13 のようになる。図 12 の 析出条件は初温 $63^{\circ} \mathrm{C}$, 外気温 $14^{\circ} \mathrm{C}$, モル比 0.55 , 種子量 $72 \mathrm{~g} / l$, 種子粒度 $20 \mu$ 以下 $7 \%$, 析出時間 113 時間で, 図 13 は初温 $8^{\circ} \mathrm{C}$, 温度傾斜 $\alpha=0.0049$, モル比 0.54 , 種子量 $65 \mathrm{~g} / l$, 種子

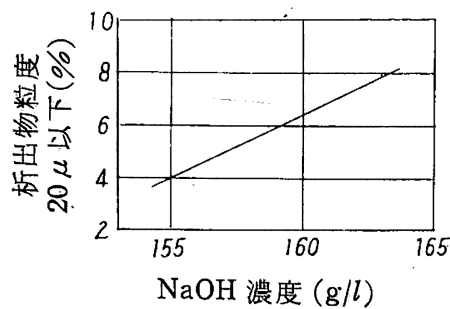

図 12 析出物粒度ーアルカリ濃度 の影響

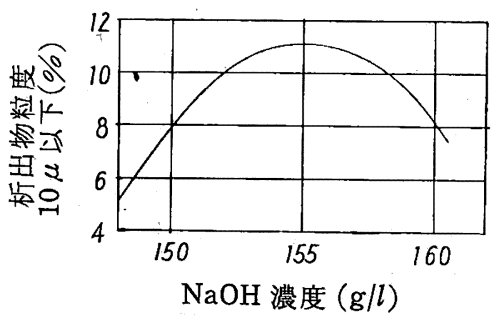

図 13 析出物粒度ーアルカリ濃度の 影響
粒度 $10 \mu$ 以下 $7 \%$, 析 出時間 95 時間に和ける 関係である。前者のよ に初温 $63^{\circ} \mathrm{C}$ の条件では アルカリ濃度が濃くなる に従い, 析出物中の細粒 部分も多くなって来るが, 後者のように初温が 58 ${ }^{\circ} \mathrm{C}$ に低下すると, $\mathrm{NaOH}$ $160 \mathrm{~g} / l$ 付近で 細粒部分 が最大になる。これは温 度が高くなるほど，細粒 部分の最大値を示すアル カリ濃度が濃い方向に移 って行く図 8 の傾向と一 致するものである。

本報告の終に当り，発表の機会を与えていただき，かつ種々の 御指導御援助を賜わった昭和電工一方井卓雄重役, 松原一郎工場 長を始め諸先鞾の方々に深く感謝の意を表わす。

\title{
アルミン酸ナトリウム溶液からの水酸化アルミニウムの 析出物粒度に対する種子の種類および量の影響†
}

\author{
（昭 和 37 年 3 月 20 日 受 理）
}

$$
\text { 下 里 純一郎* }
$$

\begin{abstract}
アルミン酸ナトリゥム溶液から析出する水酸化アルミニウム結晶の粒度に及ほする応条件の影響を前報に引続き論じ た。反応条件としては種子の種類並びに量を取り上げ，更に析出物粒径の経時変化を論じた。これらの要因の影響を調べ るための中間実験を行ない，更に従来の二，三の実験例を述べて，その影響を考察した。得られた結論は次のとおりであ る。（1）極端な条件を除いては, 種子の粒度は析出物の粒度を決定づける。しかし, 不安定な結晶, またはバイヤライ トのよ5なるのを種子として使用する時は, 種子の粒度が見掛け上粗くても細粒を析出する。また, 析出物の粒度は種子 に比較して常に大きいとは限らず，析出条件によっては種子の粒度よりも細かい析出物を得る場合も多い。（2）種子量 はある值の時に析出物粒径が最大になる条件がある。（3）析出物粒径は一般的には析出開始直後，粒径が一時増大し， 析出後期に入って細粒化する傾向を有する。しかし，著しく安定な結晶を生成する析出条件によっては，析出後期の細粒 化が起らぬ場合もある。
\end{abstract}

\section{1 緒言}

前報1)に引続きアルミン酸ナトリウム溶液から析出する際の水 酸化アルミニウムの粒度に対する反応条件の影響について述べ る。析出物の粒度は温度, 液組成以外飞も添加する種子の種類, 種子の添加量等によっても調節することが可能である。また，析 出過程に伴な 5 析出物つ粒径変動も一つの傾向を示している。

\section{2 種子の種類の影響}

種子の粒度は析出物の粒度に著しい影響を与える。ただこれは

$†$ 本報を「アルミナ製造工程より見たアルミン酸ナトリウム 溶液からの水酸化アルミニウムの析出反応(第 6 報)」と する。

* 昭和ネオプレン株式会社技術部：東京都港区芝宮本町

1）下里, 古川, 高橋, 工化 65, 1797 (1962).
他の析出条件との兼合いによって変って来るもので, 析出条件に らさわしくない粗い粒度の種子を与えた場合には水酸化アルミニ ワムの新たな析出は核の生成によのものが多くなる結果, かえっ て種子より細かいものを生成する可能性もある。一般的には種子 は析出反応を促進するものであるから，多くの場合比較的粒度の 細かいことが要求される。したがって，その範囲では析出物の粒 度の大小は, 種子の粒度の大小に対応したものが得られる。

\section{$2 \cdot 1$ 種子の種類の影響に関する析出実験}

林2)の行なった実験では析出時間 96 時間, ’ $\mathrm{NaOH}$ 154〜159 $\mathrm{g} / l$, モル比 $0.51 \sim 0.53$ の析出条件に扎いて A, B, C 3 種類の 種子を使用した結果は表 1 のようになり, 粗い種子を使用した方 が，それだけ粗い析出物を得ている。ただし，A，Bは作り方を 異にした活性種子で，Bの方が活性度が高いと見られるが，見掛

2）林，昭和電工横浜工場報 A 15 (1957). 